\title{
Do Accounting, Market, and Macroeconomic Factors Affect Financial Distress? Evidence in Indonesia
}

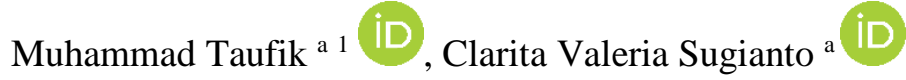 \\ ${ }^{a}$ Accounting Department, University International Batam, Indonesia
}

\section{APA Citation:}

Taufik, M., \& Sugianto, C.V. (2021). Do accounting, market, and macroeconomic factors affect financial distress? evidence in Indonesia. TIJAB (The International Journal of Applied Business), 5(2), 166-182.

Submission Date: 30/09/2021

Acceptance Date: 20/11/2021

\begin{abstract}
This paper aims to investigate the effect of accounting, market, and macroeconomic factors on financial distress. The investigations were expanded by constructing seven research models to simulate all factors. The research sample includes companies listed on the IDX from 2016 to 2020 which produce 1.710 data. This paper finds that retained earnings (RETA) and earnings (EBITTA) as part of accounting factors have a role in weakening financial distress and can be consistently tested in several research models. Equity (MVE) as part of the market factor weakens financial distress and is consistently tested. Although solvency (SOLV) was described as the company's ability to maximize debt, it is not consistently tested in several research models. Finally, it was found that deflationary conditions caused financial distress which represented macroeconomic factors. This paper makes a practical contribution to companies and governments to evade financial distress.
\end{abstract}

Keywords: financial distress; accounting; market; macroeconomic

This is an open access article under the CC BY-NC-SA license.

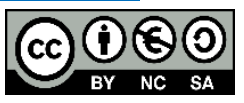

\section{Introduction}

The capital provider gives noticeable to unhealthy and healthy firms (Lizares \& Bautista, 2021). Capital providers, namely lenders and investors, prefer negative and significant movement over the company's unhealthy condition. The implications decrease to the inflow of funds, liquidity, operations, and uncertainty business so that the earning quality of the company becomes a downturn (Gerstrøm \& Isabella, 2015; Jan \& Marimuthu, 2015; Khaliq et al., 2014). Thus, it is necessary to identify whether the company is experiencing financial distress so that there are failure prevention measures (Altman et al., 2017; Dobbie et al., 2017; Hantono, 2019; Osinubi, 2020; Paule-Vianez et al., 2020).

Financial distress is different from bankruptcy (Farooq et al., 2018). Financial distress occurs after getting to be unable to pay its obligations due to negative (operational) sales, liquidity problems, and

\footnotetext{
${ }^{1}$ Corresponding author.

E-mail address: m.taufik@uib.ac.id
} 
high fixed costs. In contrast, bankruptcy is an interpretation of operations that have stopped due to a lack of understanding the company is falling to a distress zone in finance so it doesn't have enough time to immediately ameliorate (Franks et al., 2016; Mulyati, 2020).

Moreover, there is no date of time that represents the event of bankruptcy (Mohamed, 2020). We responded to Mohamed (2020) where we focused more on financial distress prediction (FDP) which is an early sign of bankruptcy. The significance of FDP is a signal to investors how the company is in line with expectations, namely being able to survive financial distress (Gerstrøm \& Isabella, 2015; Hantono, 2019; Osinubi, 2020).

Previous studies in outlining financial distress focus on accounting measurements only (Tinoco et al., 2018; Tinoco \& Wilson, 2013). By referring to the research in Indonesia, which the dominance of FDP research is affected by the use of accounting factors only such as Susanti et al. (2020), Indrajati et al. (2020), Kholisoh \& Dwiarti (2020), Monir (2020), Ogachi et al. (2020), Koske et al. (2019), Fredrick, (2019), and Kazemian et al. (2017), in point of fact the object of research does not cover all companies on the IDX. However, the empirical research of financial distress is more accurately predicted when the researcher adds market and macroeconomic measurements (Tinoco et al., 2018) and the figures become to cover the debate of accounting shortcomings (Mohamed, 2020). A deviation between the book value of assets and the market value of the same assets was caused by the conservatism accounting principle (Hillegeist et al., 2004).

Some researchers argue detecting and predicting financial distress can add market and macroeconomic variables. Not only researchers and companies, but investors, governments, and creditors have profound attention to financial distress (Alifiah, 2014) because the negative impact will be felt by them if financial distress occurs (Mohamed, 2020). Previous work, Hillegeist et al. (2004), Distinguin et al. (2010), and Gao et al. (2019) investigate the effect of accounting and market factors on financial distress. However, a few researches have dependent on market and macroeconomic variables to interpret and predict the change in the financial distress (Tinoco et al., 2018) or macroenomic only (El-Ansary \& Bassam, 2019). Three factors, namely accounting, market, and macroeconomics, have been investigated for financial distress by Tinoco \& Wilson (2013), Binh et al. (2018), and Vo et al. (2019). Thus, the contribution of this paper is to enrich the empirical results of all factors - accounting, market, and macroeconomics, specifically in Indonesia.

The rest of the paper is revealed as the following. The second part discusses hypotheses development. The third part discusses method and research model. Results and discussion in the fourth and fifth sections. The last part is the conclusion, limitations, and suggestions for future research.

\section{Literature Review}

\subsection{Accounting Factors}

Previous work has used various predictive models of financial distress such as the Altman Z-score (Koske et al., 2019), Zmijewski (Alali et al., 2018), Springate (Prasetiyani \& Sofyan, 2020), Grover (Gusni et al., 2019), Beneish M-score (Mavengere, 2015), and Ohlson O-score (Lawrence et al., 2015). From a number of financial distress prediction models, the Altman Z-score model is considered to be more capable of measuring accounting factors in influencing the company's financial distress than other models (Puro et al., 2019; Syamni et al., 2018; Tanjung, 2020). The higher the Altman Z-Score score, the higher the company is from experiencing financial distress (Thai et al., 2014). The model of the Altman Z-Score is presented as follows.

Table 1. Altman Z-score model 


\begin{tabular}{ccl}
\hline Model & Formula & \multicolumn{1}{c}{ Result } \\
\hline \multirow{2}{Z}{ Z- } & $Z-$ score $=6.56 X 1+3.26 X 2+$ & $\mathrm{ZS}>2,60=$ Safe Zone \\
Score & $6.72 X 3+1.05 X 4$ & $1,10<\mathrm{ZS}>2,60=$ Grey Zone \\
& & $\mathrm{ZS}<1,10=$ Financial Distress Zone \\
\hline
\end{tabular}

Notes: $\mathrm{X} 1$ is working capital to total asset, $\mathrm{X} 2$ is retained earning to total asset, $\mathrm{X} 3$ is earning before interest rate and tax to total asset, $\mathrm{X} 4$ is book value of equity to total liabilities.

First, Moch et al. (2019) argue that the working capital to total asset (WCTA) ratio is the difference between current assets and current liabilities with total assets. Lord et al. (2020) argue that the WCTA ratio is a ratio that describes the strength of a company in paying off its obligations without relying on external funding and without having to liquidate current assets. The larger the number generated by this ratio indicates the company is increasingly able to handle its bills so that the company is further away from financial distress (Ally \& Bwana, 2019). The empirical investigation has proven Moch et al. (2019), Thinh et al. (2020), Bhavani \& Amponsah (2017), Januri et al. (2017) which shows that higher WCTA keeps companies from financial distress.

Second, based on research conducted by Khaliq et al. (2014), retained earnings total asset (RETA) is a ratio that measures the level of retained earnings compared to the company's total assets. Khurshid (2013) argues that the greater the net profit generated by the company, the less dependent the company is on debt. Thus, the company has sufficient sources of capital structure to face future business operations where the source of the capital structure is retained earnings which do not give rise to cash outflow options. Thus, RETA shows companies that are far from financial distress (Binh et al., 2018). Empirical investigations on this subject have been found by Charalambakis \& Garrett (2019), Monir (2020), Babatunde et al. (2017), and Saini (2018).

Third, Thai et al. (2014) explains that the earnings before interest rate and tax to total assets (EBITTA) ratio is used to measure the company's ability to generate net income using its assets. Thai et al. (2014) argue that the company will be far from financial distress if it has a large net profit but with small assets. This illustrates the company is able to efficiently use assets. Thus, EBITTA is suspected to have a negative and significant relationship with financial distress where this assumption is confirmed from the results of empirical tests by Lukason \& Laitinen (2018), Matturungan et al. (2017), Alifiah (2014), and Bauweraerts (2016).

Fourth, Lord et al. (2020) argue book value of equity to total liabilities (BVETL) ratio reflects the size of the company's equity because it measures the net worth of the company's liabilities. Furthermore, he explained that the use of book value is able to provide an overview of financial health by examining net assets in relation to total liabilities. Lord et al. (2020) also explains that companies with a higher percentage of net assets than total liabilities are better able to overcome financial distress, therefore the ratio of the book value of equity to total liabilities has a significant negative effect on financial distress. This is in line with the results of research conducted by Toly et al. (2020) and Altman et al. (2014). Referring to the discussion above, we propose hypotheses as follows:

H1: Working capital to total assets ratio has a significant negative relationship to financial distress.

$\mathrm{H} 2$ : Retained earnings to total assets ratio has a significant negative relationship to financial distress.

H3: Earnings before interest rate and tax ratio has a significant negative relationship to financial distress.

H4: Book value of equity to total liabilities ratio has a significant relationship to financial distress. 


\subsection{Accounting Factors}

Distance-to-Default Merton Model can affect the company's financial distress which consists of market value of equity, solvency, equity volatility, and stock price. The Merton model as a representation of market factors is used to evaluate and analyze credit risk where this has been widely used in empirical research (Anuwar \& Jaffar, 2017; Fischer et al., 2019; Jessen \& Lando, 2015). Thus, the market factors that will be observed in this study include market value of equity (MVE), solvency (SOLV), equity volatility (EVOL), and stock price (SPRI). First, the declining market value of equity (MVE) indicates that the company is experiencing financial distress (Khaliq et al., 2014). This is appropriate with the results of research conducted by Binh et al. (2018) and Vo et al. (2019).

Second, solvency is a ratio that measures how much inflow of funds comes from debt or measures the company's ability to pay off its obligations (Khaliq et al., 2014). Kristanti \& Herwany (2017) and (Olariu, 2016) suggest that the higher the company's solvency, the closer the company is to financial distress, this is because the higher the company's solvency indicates that all the capital owned by the company is used to guarantee company liabilities. This is appropriate with the results of research conducted by Kristanti \& Herwany (2017), and Rafatnia et al., (2020).

Third, in respect to volatility equity, Arlov et al. (2013) explained that the higher the level of equity volatility describes the high possibility the company's assets are far below the company's liabilities, which means the company is in a state of financial distress. Several circumstances make equity volatility have an effect on financial distress. This is appropriate with the results of research by Arlov et al. (2013), Li \& Faff (2019), Jia et al. (2020), Bauer \& Agarwal (2014), and Tian et al. (2015).

Fourth, in respect to the stock price, Kristanti \& Herwany (2017) reveal that one of the benchmarks for the success of a company's management is assessed through the company's stock price. The higher the value of the company's share price, the higher the value of the company in the perspective of shareholders. This is the result of management in managing the company and reducing agency problems. This argument is supported by empirical findings that stock prices have a significant negative effect on financial distress found by Binh et al. (2018), Nouri \& Soltani (2016), and Fredrick (2019). Referring to the discussion above, we propose hypotheses as follows:

H5: Market value of equity has a significant negative relationship to financial distress

H6: Solvency has a significant positive relationship to financial distress

H7: Volatility has a significant positive relationship to financial distress

H8: Stock price has a significant negative relationship to financial distress

\subsection{Economic Factors}

First, the treasury bills used are the annual yield of one-year government bonds Binh et al. (2018). Tinoco \& Wilson (2013) show that when government bonds have a high value, it will cause interest rates to rise and it will make the level of financial distress rise. This indicates that the treasury bills has a significant positive effect on financial distress, this is appropriate with the results of research conducted by Binh et al. (2018) and Tinoco et al., (2018).

Second, Kholisoh \& Dwiarti (2020) define inflation as a condition where there is a general and continuous increase in prices. Moreover, Kholisoh \& Dwiarti (2020) and Setyawati \& Amelia (2018) reveal that inflation can affect the price of goods to be high and the ability of buyers to decline, thereby reducing the company's sales turnover. This shows that the higher the inflation rate, the higher the possibility of financial distress. This is appropriate with the results of research conducted by (Moravec, 2013) and (Li et al., 2021). Referring to the discussion above, we propose hypotheses as follows: 
H9: Treasury bills has a significant positive relationship to financial distress

H10: Inflation has a significant positive relationship to financial distress

\section{Method}

The data used in this study were obtained from the financial statements of all companies listed on the Indonesia Stock Exchange for the period 2016 to 2020. This study uses purposive sampling with the criteria of issuing financial statements that have been completely audited from 2016 to 2020 and have all the data needed in the study. Furthermore, data on stock prices were obtained from the annual closing price around 28 until 31 december available at www.idx.co.id. Also, the company's stock price at the end of each month around 27 to 31 is needed to meet the measurement of equity volatility. Annual inflation data were obtained from www.bi.go.id, and data on the treasury bills were obtained from the website www.investing.com. Altman Z-Score Model, Merton Model, and several macroeconomic indicators are used to predict financial distress. In detail, the result of the interest coverage ratio that is less than 1 is classified as suffering financial distress and is given a dummy value of 1 , vice versa. Table 2 shows the variables used in this study.

Table 2. Variable measurement

\begin{tabular}{|c|c|c|c|}
\hline Category & Variable and abreviation & Symbol & Formula \\
\hline \multirow[b]{2}{*}{$\begin{array}{l}\text { Financial } \\
\text { Distress }\end{array}$} & \multirow[b]{2}{*}{ Financial Distress } & \multirow[b]{2}{*}{$\mathrm{Y}$} & \multirow{2}{*}{$\begin{array}{c}\text { Interest coverage ratio }=\frac{E B I T}{\text { Interest Expense }} \\
\text { (zero if the company does not experience } \\
\text { financial distress, and } 1 \text { if otherwise). }\end{array}$} \\
\hline & & & \\
\hline \multirow{8}{*}{ Accounting } & \multirow{2}{*}{$\begin{array}{l}\text { Working capital to total assets } \\
\text { ratio (WCTA) }\end{array}$} & \multirow{2}{*}{$\mathrm{X} 1$} & Working capital \\
\hline & & & Total assets \\
\hline & \multirow{2}{*}{$\begin{array}{l}\text { Retained earnings to total } \\
\text { assets ratio (RETA) }\end{array}$} & \multirow{2}{*}{$\mathrm{X} 2$} & Retained Earnings \\
\hline & & & Total assets \\
\hline & \multirow{2}{*}{$\begin{array}{l}\text { Earnings Before Interests Rate } \\
\text { and Taxes to total assets ratio } \\
\text { (EBITTA) }\end{array}$} & \multirow{2}{*}{$\mathrm{X} 3$} & EBIT \\
\hline & & & $\overline{\text { Total assets }}$ \\
\hline & \multirow{2}{*}{$\begin{array}{l}\text { Book value of equity to total } \\
\text { liabilities ratio (BVETL) }\end{array}$} & \multirow{2}{*}{$\mathrm{X} 4$} & Book value of equity \\
\hline & & & Total liabilities \\
\hline \multirow{5}{*}{ Market } & Market value of equity (MVE) & $\mathrm{X} 5$ & log natural of Price $\times$ Outstanding shares \\
\hline & \multirow{2}{*}{ Solvency (SOLV) } & \multirow{2}{*}{ X6 } & Totatal liabilities \\
\hline & & & $\overline{\text { Total MVE + Total liabilites }}$ \\
\hline & Equity volatility (EVOL) & $\mathrm{X} 7$ & Stock return's standard deviation per month \\
\hline & Stock price (SPRI) & $\mathrm{X} 8$ & Closing price \\
\hline \multirow{2}{*}{$\begin{array}{c}\text { Macro } \\
\text { economic }\end{array}$} & Treasury bills (TBIL) & X9 & Government bond interest rate one year \\
\hline & Inflation (INFL) & $\mathrm{X} 10$ & Annual inflation \\
\hline
\end{tabular}

The seven research model to test and prove the hypotheses were logistic regression that using Stata 18. Model 1 consists of all independent variables accounting, market, and macroeconomic factors. Model 2 consists of independent variables accounting factors, market factors in model 3, and macroeconomic factors in model 4 . Model 5 consists of independent variables accounting and market factors. Model 6 consists of independent variables accounting and macroeconomic factors. The last is 
model 7 which consists of the independent variables of market and macroeconomic factors. These research models can be expressed in the following equation:

$$
\begin{aligned}
& Y=\beta_{0}+\beta_{1} W_{C T A_{1}}+\beta_{2} \text { RETA }_{2}+\beta_{3} \text { EBITTA }_{3}+\beta_{4} B V E T L_{4}+\beta_{5} M V E_{5}+\beta_{6} \text { SOLV }_{6}+\beta_{7} E_{V O L} \\
& +\beta_{8} S P R I_{8}+\beta_{9} T B I L_{9}+\beta_{10} I N F L_{10}+\varepsilon \ldots \ldots \text { (1) } \\
& Y=\beta_{0}+\beta_{1} W C T A_{1}+\beta_{2} \text { RETA }_{2}+\beta_{3} \text { EBITTA }_{3}+\beta_{4} \text { BVETL }_{4}+\varepsilon \\
& Y=\beta_{0}+\beta_{5} M V E_{5}+\beta_{6} \operatorname{SOLV}_{6}+\beta_{7} E V O L_{7}+\beta_{8} S P R I_{8}+\varepsilon \ldots \ldots(3) \\
& Y=\beta_{0}+\beta_{9} T B I L_{9}+\beta_{10} I N F L_{10}+\varepsilon \ldots \ldots(4) \\
& Y=\beta_{0}+\beta_{1} W_{C T A_{1}}+\beta_{2} \text { RETA }_{2}+\beta_{3} \text { EBITTA }_{3}+\beta_{4} \text { BVETL }_{4}+\beta_{5} M V E_{5}+\beta_{6} \text { SOLV }_{6}+\beta_{7} \text { EVOL }_{7} \\
& +\beta_{8} S P R I_{8}+\varepsilon \ldots \ldots(5) \\
& Y=\beta_{0}+\beta_{1} W C T A_{1}+\beta_{2} R E T A_{2}+\beta_{3} \text { EBITTA }_{3}+\beta_{4} B V E T L_{4}+\beta_{9} T B I L_{9}+\beta_{10} I N F L_{10} \\
& +\varepsilon \ldots \ldots \text { (6) } \\
& Y=\beta_{0}+\beta_{5} M V E_{5}+\beta_{6} S O L V_{6}+\beta_{7} E V O L_{7}+\beta_{8} S P R I_{8}+\beta_{9} T B I L_{9}+\beta_{10} I N F L_{10}+\varepsilon
\end{aligned}
$$

\section{Results}

\subsection{Descriptive Analysis}

The interest coverage ratio is the most common tool in classifying firms into distressed groups (Mohamed, 2020). The data used are company data listed on the Indonesia Stock Exchange with a total of 1,710 observation data. Finally, table 3 shows the observation data divided into two groups, namely 1,175 observation data or $68.7 \%$ did not experience financial distress and 535 data or $31.3 \%$ experienced financial distress.

Furthermore, table 4 shows the results of descriptive statistical tests for each independent variable. The ratio of working capital to total assets (WCTA) has an average value with $40 \%$ which indicates companies in Indonesia are still able to pay off their obligations due to the adequacy of their assets. Therefore, it is necessary to investigate empirically whether the average value of WCTA (40\%) do not evoke financial distress.

The variable-ratio of retained earnings to total assets (RETA) has an average value of - $36 \%$ which indicates companies in Indonesia prefer to distribute their profits to shareholders in the form of dividends, allegedly to maintain credence investors. This is confirmed by looking at the average value of the ratio of working capital to total assets (WCTA) with $40 \%$ which indicates that investors are loyal to the company. Thus, it is interesting to confirm empirically whether the company's strategy in distributing profits has positive implications for the absence of financial distress.

The average value of earnings before interest and taxes on total assets (EBITTA) is 5\% which indicates companies in Indonesia can generate profits 5 times the value of assets so that it can be concluded companies have the power to sell and create profits. The noticeable point, the findings of this descriptive analysis strengthen another accounting factors, namely the high sales value or RETA which prioritizes break-even and gain to investors. Thus, it is interesting to explore the role of EBITTA allegedly evading financial distress. 
The variable-ratio of the book value of equity to total liabilities (BVETL) has an average value of 7.27 which indicates the ability of companies in Indonesia to pay off their obligations using their capital is very large. Overall, WCTA, RETA, EBITTA, and BVETL have a good performance of accounting ratio. Therefore, it is necessary to estimate whether all of these ratios have a role to reduce bankruptcy potential.

Furthermore, market factors as part of external factors have a role in giving implications for the company's financial distress. Market factors are represented by four variables, namely market value of equity (MVE), solvency (SOLV), equity volatility (EVOL) and stock price (SPRI). First, the market value of equity has an average value of 29.177884 which indicates the natural log of the stock price multiplied by the outstanding share. The higher the MVE value, the more financial distress will be evaded. Second, the solvency variable has an average value of $46.46 \%$ which represents the company's operations supported by debt. So, it is necessary to empirically test whether it is true that high corporate debt causes financial distress. Third, the equity volatility (EVOL) variable shows an average value of 353.10 which is a representation of the standard deviation of stock returns. Zhang et al. (2009) argue that the higher EVOL value, the greater asset volatility leads to financial distress. Fourth, the company's stock price shows an average of Rp 2,057 where the higher the company's share price reflects investor trust to companies so that financial distress is increasingly evaded.

The third factor in this study is the macroeconomic, namely the one-year government bond interest rate or treasury bills (TBIL) and inflation (INFL). The treasury bills variable has an average value of $5.60 \%$. Otherwise, the inflation variable has an average value of $2.83 \%$. The expected inflation value is the inflation rate that does not fluctuate and is low so is not render financial distress. Referring to PMK No. 93/PMK.011/2014 and PMK No. 124/PMK.010/2017, the inflation rate set by the regulator from 2016 to 2020 is $4.0 \%, 4.0 \%, 3.5 \%, 3.5 \%$, and $3 \%$ consecutively. It is interesting to examine whether the difference between the target and the realization value of inflation affects financial distress. Thus, all average numbers show the characteristics of each variable.

Table 3. Grouping of companies based on financial distress

\begin{tabular}{cccc}
\hline Variabel & Classification & Frequency & Percentage \\
\hline Interest & 0 : Companies do not experience financial distress & 1.175 & 68,7 \\
coverage & 1: Companies experience financial distress & 535 & 31,3 \\
ratio & Total & 1.710 & 100 \\
\hline
\end{tabular}

Table 4. The results of descriptive analysis of accounting, market, and macroenomic factors

\begin{tabular}{lrrrrr}
\hline \multicolumn{1}{c}{ Variabels } & \multicolumn{1}{c}{$\mathrm{N}$} & \multicolumn{1}{c}{ Max } & \multicolumn{1}{c}{ Min } & \multicolumn{1}{c}{ Mean } & \multicolumn{1}{c}{ Std Dev } \\
\hline WCTA (x 100\%) & 1.710 & 5,509924 & $-37,656048$ & 0,040117 & 1,393114 \\
RETA (x 100\%) & 1.710 & 20,052585 & $-118,561391$ & $-0,366017$ & 4,924397 \\
EBITTA (x 100\%) & 1.710 & 1,266642 & $-1,177132$ & 0,050669 & 0,127165 \\
BVETL (n) & 1.710 & $3.536,34$ & $-0,989009$ & 7,273303 & 118,791894 \\
MVE (log natural) & 1.710 & 33,94127 & 22,90368 & 28,28170 & 1,96149 \\
SOLV (x 100\%) & 1.710 & 0,99209 & 0,00033 & 0,46462 & 0,26302 \\
EVOL (std deviasi of stock & 1.710 & $48.157,80$ & 0,00 & 353,10 & $1.437,78$ \\
return) & & & & &
\end{tabular}




\begin{tabular}{lcrrrr}
\hline \multicolumn{1}{r}{ Variabels } & $\mathrm{N}$ & \multicolumn{1}{c}{ Max } & \multicolumn{1}{c}{ Min } & \multicolumn{1}{c}{ Mean } & \multicolumn{1}{c}{ Std Dev } \\
\hline SPRI (Rp) & 1.710 & 83.800 & 50 & 2.057 & $5.365,89$ \\
TBIL & 1.710 & 0,07463 & 0,04239 & 0,056012 & 0,010718 \\
INFL & 1.710 & 0,0361 & 0,0168 & 0,02832 & 0,006434 \\
\hline
\end{tabular}

Notes: WCTA is working capital to total assets ratio; RETA is retained earnings to total assets ratio; EBITTA is earnings before interests rate and taxes to total assets ratio; BVETL is book value of equity to total liabilities ratio; MVE is market value of equity; SOLV is solvency; EVOL is equity volatility; SPRI is stock price; TBIL is treasury bills; INFL is inflation.

\subsection{Results of Hypotheses}

In this section, we focus to describe model 1, namely the influence of all variables from accounting, market and macroeconomic factors on financial distress to answer the research hypotheses. In contrast, the other models namely models 2, 3, 4, 5, 6, and 7 were shown in the discussion section.

The first model represents financial distress which is influenced by all accounting factors, namely WCTA, RETA, EBITTA, and BVETL, market factors namely MVE, SOLV, EVOL, and SPRI, and macroeconomic factors namely TBIL and INFL. First, the ratio of working capital to total assets (WCTA) does not affect financial distress, with a value of -0.0179 . The results of this study are appropriate with research conducted by Ramadhan \& Marindah (2021). Second, the retained earnings ratio variable on total assets (RETA) has a negative and significant effect on financial distress, scoring -0.00784 with the error rate of $10 \%$. This means that companies stay away from the financial distress zone. If this result is related to descriptive statistics, it can be concluded that because the company distributes more profits to investors in the form of dividends than retained earnings, it creates trust from investors. Companies that distribute more profits in the form of dividends than retained earnings generate enterprise good news from investors in the form of company income expectations that will continue to be good in the future (Al-Shattarat et al., 2018). The results of this study are appropriate with research conducted by Charalambakis \& Garrett (2019), Monir (2020), Saini (2018), and Babatunde et al. (2017). Third, the variable earnings before interest and taxes on total assets (EBITTA) have a negative and significant effect on financial distress, scoring -1.463 with the error rate of $1 \%$. This means that the company is moving away from the financial distress zone due to good EBITTA performance. This is confirmed from table 4 that the companies able to create a profit 5 times greater than their assets. Thai et al., (2014) explain that a company is far from the financial distress zone if it has a large net profit with existing assets. This is because the company has efficiency in maximizing assets to generate income. The results of this study are appropriate with research conducted by Lukason \& Laitinen (2018), Matturungan et al. (2017), Alifiah (2014), and Bauweraerts (2016). Fourth, the variable book value of equity to total liabilities (BVETL) does not affect financial distress, with a value of 0.00009 .

The fifth is the market value of equity (MVE) variable which represents the group of market factors showing a negative and significant effect on financial distress, scoring - 0.0433 with the error rate of $1 \%$. The company stays away from the financial distress zone because of the performance of MVE. If we refer to the descriptive statistics of MVE value, it means MVE value which is the natural log of the market price multiplied by the outstanding share, keeps the company from the financial distress zone. Moreover, the average share value of the company increases and the volume of business from trading also increases. This supports the analysis of RETA's findings that the company focuses on investor returns. This study is appropriate with the work by Khaliq et al. (2014) where the market value of a company's equity that has not decreased indicates that the company is not experiencing financial distress. Sixth, the solvency variable (SOLV) has a negative and significant effect on financial distress, scoring -0.0394 with the error rate of $5 \%$. The descriptive test result shows that the debt level of $46.46 \%$ which 
is considered to be quite high does not undermine the company's attention in allocating financial resources and has no implications for financial distress. This means that companies in Indonesia adopt the paradigm of trade off theory, namely, there is value that can be optimized from debt to finance activities, operations and maintain company liquidity (Harjito, 2016; Tong \& Green, 2005). However, it should be noted that debt can also provide an obligation for companies in the form of scheduled principal and interest obligations and consequences of penalties and lawsuits in financial and nonfinancial forms due to moral hazard. Therefore, this paper underlines that the level of debt that can be justified to stay away from the financial distress zone is a maximum of $46 \%$ where this level is confirmed from the results of the statistical descriptive test in table 4. This result is appropriate with research conducted by Yazdanfar \& Öhman (2020), Santosa et al., (2020), Alifiah \& Tahir (2018). Seventh, the equity volatility (EVOL) variable does not affect financial distress, with a value of 20,306. Eighth, the stock price variable does not affect financial distress, with a value of 70,608.

The ninth variable is treasury bills (TBIL) which represents a group of macroeconomic factors which shows no effect on financial distress, with a value of -0.906 . The last or tenth variable, namely the inflation variable (INFL) shows a negative and significant effect on financial distress, scoring -0.0753 with the error rate of 5\%. Sequentially, the inflation set by the regulator since $2016-2020$ is $4.0 \%, 4.0 \%$, $3.5 \%, 3.5 \%$, and $3 \%$. By referring to the descriptive statistics in table 4 , the average inflation rate is $2.83 \%$ or $1.17 \%$ lower than the inflation rate set. This means that the condition experienced by the Indonesian economy is deflation, which is a decrease in purchasing power. Thus, from a macroeconomic perspective, Indonesia does not have good economic fundamentals, wherein substance, the level of deflation causes financial distress in companies. The government needs to carry out several economic policies to get out of the deflation zone.

Table 5. Regression test result

\begin{tabular}{|c|c|c|c|c|c|c|c|c|}
\hline Variabel & Expected & Model 1 & Model 2 & Model 3 & Model 4 & Model 5 & Model 6 & Model 7 \\
\hline \multirow[t]{2}{*}{ WCTA } & $(-)$ & -0.0179 & -0.0163 & n.a. & n.a. & -0.0195 & -0.0144 & n.a. \\
\hline & & $(0.0141)$ & $(0.0142)$ & n.a. & n.a. & $(0.0141)$ & $(0.0141)$ & n.a. \\
\hline \multirow[t]{2}{*}{ RETA } & $(-)$ & $-0.00784^{*}$ & $-0.00979 * *$ & n.a. & n.a. & $-0.00805^{*}$ & $-0.00965^{* *}$ & n.a. \\
\hline & & $(0.00432)$ & $(0.00434)$ & n.a. & n.a. & $(0.00433)$ & (0.00434) & n.a. \\
\hline \multirow[t]{2}{*}{ EBITTA } & $(-)$ & $-1.463 * * *$ & $-1.576 * * *$ & n.a. & n.a. & $-1.507 * * *$ & $-1.532 * * *$ & n.a. \\
\hline & & $(0.0811)$ & $(0.0771)$ & n.a. & n.a. & $(0.0805)$ & $(0.0779)$ & n.a. \\
\hline \multirow[t]{2}{*}{ BVETL } & $(-)$ & 0.00009 & $0.000155^{*}$ & n.a. & n.a. & $9.09 \mathrm{e}-05$ & $0.000161^{*}$ & n.a. \\
\hline & & $(0.00008)$ & $(8.30 \mathrm{e}-05)$ & n.a. & n.a. & $(8.67 \mathrm{e}-05)$ & $(8.29 \mathrm{e}-05)$ & n.a. \\
\hline \multirow[t]{2}{*}{ MVE } & $(-)$ & $-0.0433 * * *$ & n.a. & $-0.0686 * * *$ & n.a. & $-0.0420 * * *$ & n.a. & $-0.0696^{* * *}$ \\
\hline & & $(0.00835)$ & n.a. & $(0.00986)$ & n.a. & $(0.00834)$ & n.a. & $(0.00984)$ \\
\hline \multirow[t]{2}{*}{ SOLV } & $(+)$ & $-0.0394 * *$ & n.a. & -0.00699 & n.a. & $-0.0367 * *$ & n.a. & -0.0152 \\
\hline & & $(0.0160)$ & n.a. & $(0.0174)$ & n.a. & $(0.0160)$ & n.a. & $(0.0174)$ \\
\hline \multirow[t]{2}{*}{ EVOL } & $(+)$ & 20.306 & n.a. & -27.506 & n.a. & 11.206 & n.a. & $-1.06 e-06$ \\
\hline & & -61.206 & n.a. & -65.506 & n.a. & -61.206 & n.a. & $(6.49 \mathrm{e}-06)$ \\
\hline \multirow[t]{2}{*}{ SPRI } & $(-)$ & 70.608 & n.a. & -35.306 & n.a. & -12.707 & n.a. & $-2.78 \mathrm{e}-06$ \\
\hline & & -27.006 & n.a. & -31.406 & n.a. & -27.006 & n.a. & $(3.13 \mathrm{e}-06)$ \\
\hline \multirow[t]{2}{*}{ TBIL } & $(+)$ & -0.906 & n.a. & n.a. & -1.119 & n.a. & -0.690 & -1.219 \\
\hline & & $(0.847)$ & n.a. & n.a. & $(0.890)$ & n.a. & $(0.847)$ & $(0.893)$ \\
\hline
\end{tabular}




\begin{tabular}{lcccccccc}
\hline Variabel & Expected & Model 1 & Model 2 & Model 3 & Model 4 & Model 5 & Model 6 & Model 7 \\
\hline INFL & $(+)$ & $-0.0753^{* *}$ & n.a. & n.a. & $-0.163^{* * *}$ & n.a. & $-0.0766^{* *}$ & $-0.150^{* * *}$ \\
& & $(0.0347)$ & n.a. & n.a. & $(0.0364)$ & n.a. & $(0.0349)$ & $(0.0364)$ \\
Obs & & 1,710 & 1,710 & 1,710 & 1,710 & 1,710 & 1,710 & 1,710 \\
\hline
\end{tabular}

Notes: model 1 is accounting, market, and macroeconomic factors; model 2 is accounting factors; model 3 is market factors; model 4 is macroeconomic factors; model 5 is accounting and market factors; model 6 is accounting and macroeconomic factors; and model 7 is market and macroeconomic factors; *,**, *** indicate significance at the $10 \%, 5 \%$, and $1 \%$ levels.

\section{Discussion}

In this discussion section, we describe models 2 through 7 to test the consistent empirical results of model 1 covering all variables and research hypotheses. The second model is a test of financial distress which is influenced by accounting factors only. Referring to table 5, the results are consistent with model 1 where the RETA variable has a negative and significant effect on financial distress, scoring -0.00979 with the error rate of 5\%. This means that the company's preference for profit sharing is the distribution of dividends compared to retained earnings to signal that the company has high earnings prospects in the future (Al-Shattarat, 2020). Furthermore, consistent results were also found that the EBITTA variable had a negative and significant effect, scoring -1.576 with the error rate of $1 \%$. This means that strengthening RETA where the company has a high level of income so that it gives a signal on profit sharing and the prospect earning of future as well (Al-Shattarat et al., 2018).

The third model is a test of financial distress which is influenced by market factors only. Referring to table 5, the results are consistent with model 1 where the market value of equity (MVE) has a negative and significant effect, scoring -0.0686 with the error rate of $1 \%$. These results indicate that there is a relationship between high stock prices and trading volume with low financial distress, which supports RETA concerning investor trust.

The fourth model is a test of financial distress which is only influenced by macroeconomic factors. Referring to table 5, the results are consistent with model 1 where inflation (INFL) has a negative and significant effect, scoring -0.163 with the error rate of $1 \%$. This result strengthens the previous analysis, that the macroeconomic substance, companies in Indonesia are experiencing a deflationary stage, namely a decline in purchasing power because the inflation rate in the field is lower than the inflation rate that has been set $(2.83 \%$ versus $4.0 \%, 4.0 \%, 3.5 \%, 3.5 \%$ and $3 \%$ in 2016-2020) - not inflation.

The fifth model is a test of financial distress which is influenced by a combination of accounting and market factors. All variables of accounting factors are consistent with the results of model 1 and model 2, RETA has a negative and significant effect on financial distress, scoring -0.00805 with the error rate of $10 \%$. The EBITTA variable also consistently has a negative and significant effect on financial distress, scoring -1.507 with the error rate of $1 \%$. From the market factors, it was also found that the results were consistent with model 1 and model 3 where the MVE variable had a negative and significant effect on financial distress, scoring -0.0420 with the error rate of $1 \%$.

The sixth model is a test of financial distress which is influenced by a combination of accounting and macroeconomic factors. The variables RETA and EBITTA remain consistent with models 1, 2, and 5. RETA has a negative and significant effect on financial distress, scoring -0.00965 with the error rate of $5 \%$. Moreover, EBITTA has a negative and significant effect on financial distress, scoring -1.532 with the error rate of $1 \%$. Likewise, with RETA and EBITTA, the inflation variable (INFL) is also consistent with models 1 and 4, which has a negative and significant effect on financial distress, scoring -0.0766 with the error rate of $5 \%$. 
Finally, the seventh model is a test of financial distress which is influenced by a combination of market and macroeconomic factors. This model also shows that all MVE from market factors and inflation (INFL) from economic factors have a negative and significant effect on financial distress. The significant value of MVE is -0.0696 with an error rate of $1 \%$. Moreover, the significant value of inflation is -0.150 with an error rate of $1 \%$.

Referring to all models and consistency of results, it can be concluded that the RETA and EBITTA variables are part of the accounting factors that consistently have implications for evading financial distress. This means that companies need to maintain the company's behaviour to prefer to share profits with investors - such as dividends. The company can also focus on the future to maintain a stable rising revenue level. The MVE variable which is part of the consistent market factor in each test has implications for evading financial distress. The company has earned the trust of investors, which is represented by the stock price so that in the future the company needs to maintain events that contain good news to maintain this. Another variable from the market, namely SOLV, is significantly negative in model 1 and consistent results in model 5 but inconsistent that does not affect financial distress in models 3 and 7. Finally, the INFL variable shows the consistency in models $1,4,6$, and 7. Inflation is the external environment of the company that is not able to be controlled. If referring to Alifiah (2014), the government is also affected if the company experiences financial distress, so the government needs to develop economic policies that are more likely to improve economic fundamentals such as improving purchasing power.

\section{Conclusions}

This study uses 7 research models to examine accounting, market, and macroeconomic factors on financial distress. Accounting factors that have contributed to evading financial distress are RETA and EBITTA, while WCTA and BVETL do not affect all models. The only market factor that affects financial distress is MVE in all research models which represents stock prices which have implications for a decrease in financial distress. Moreover, SOLV affects evading financial distress, where the company has a debt level that can be maximized and can anticipate the consequences of debt, namely principal and interest. However, SOLV is not consistent across several research models. INFL is a variable that represents part of macroeconomic factors that have a relationship with financial distress. However, because the descriptive test shows the inflation rate is below the set rate, it means that Indonesia is in a deflationary zone, so that significant negative effects need to be considered by the government.

This study provides several noteworthy implications for companies and regulators. Companies need to consider maintaining and consistent to distribute of principal returns to investors (RETA), maintaining sales (EBITTA), producing good news to maintain stability in rising share prices (MVE), and maintaining controlled debt levels (SOLV). Lastly, the government needs to anticipate the consequences of deflation which reduces purchasing power.

Purchasing power is part of macroeconomic factors that we do not observe. This happened because we face lack of available data and literature reviews. Furthermore, the next writer can consider the variables that have been studied by Hu \& Zheng (2015) and Paule-Vianez et al., (2020) to capture until 32 variables. We did not adopt all variables due to the limited availability of literature review in constructing the hypothesis. 


\section{References}

Al-Shattarat, W. K., Al-Shattarat, B. K., \& Hamed, R. (2018). Do dividends announcements signal future earnings changes for Jordanian firms? Journal of Financial Reporting and Accounting, 14(1), $1-20$.

Alali, M. S., Bash, A. Y., Alforaih, E. O., Alsabah, A. M., \& Alsalem, A. S. (2018). The adaptation of Zmijewski Model in appraising the financial distress of mobile telecommunications companies listed at Boursa Kuwait. International Academic Journal of Accounting and Financial Management, 5(4), 129-136. www.iaiest.com

Alifiah, M. N. (2014). Prediction of financial distress companies in the trading and services sector in Malaysia using macroeconomic variables. Procedia - Social and Behavioral Sciences, 129, 90-98. https://doi.org/10.1016/j.sbspro.2014.03.652

Alifiah, M. N., \& Tahir, M. S. (2018). Predicting financial distress companies in the manufacturing and non-manufacturing sectors in Malaysia using macroeconomic variables. Management Science Letters, 8(6), 593-604. https://doi.org/10.5267/j.msl.2018.4.031

Ally, O. J., \& Bwana, K. M. (2019). Testing financial di stress of manufacturing firms in Tanzania: an application of altman z-score model. Business Education Journal, II(II), 1-13.

Altman, E. I., Iwanicz-Drozdowska, M., Laitinen, E. K., \& Suvas, A. (2014). Distressed firm and bankruptcy prediction in an international context: A review and empirical analysis of Altman's ZScore Model. SSRN Electronic Journal, 2. https://doi.org/10.2139/ssrn.2536340

Altman, E. I., Iwanicz-Drozdowska, M., Laitinen, E. K., \& Suvas, A. (2017). Financial distress prediction in an international context: A review and empirical analysis of Altman's Z-Score Model. Journal of International Financial Management and Accounting, 28(2), 131-171. https://doi.org/10.1111/jifm.12053

Anuwar, M. H., \& Jaffar, M. M. (2017). Grading the probabilities of credit default risk for Malaysian listed companies by using the KMV-Merton model. AIP Conference Proceedings, 1870(June). https://doi.org/10.1063/1.4995857

Arlov, O., Rankov, S., \& Kotlica, S. (2013). Cash flow in predicting financial distress and bankruptcy. Advances in Environmental Science and Energy Planning, 88-93. SERBIA\%0Aoarlov@megatrend.edu.rs, rankovs@megatrend.edu.rs, kotlicasl@megatrend.edu.rs\%0A

Babatunde, A. A., Akeju, J. B., \& Malomo, E. (2017). The effectiveness of Altman's Z -Score in predicting bankruptcy of quoted manufacturing companies in Nigeria. European Journal of Business, Economics and Accountancy, 5(5), 74-83.

Bauer, J., \& Agarwal, V. (2014). Are hazard models superior to traditional bankruptcy prediction approaches? A comprehensive test. Journal of Banking and Finance, 40(1), 432-442. https://doi.org/10.1016/j.jbankfin.2013.12.013

Bauweraerts, J. (2016). Predicting bankruptcy in private firms: towards a stepwise regression procedure. International Journal of Financial Research, 7(2). https://doi.org/10.5430/ijfr.v7n2p147

Bhavani, G., \& Amponsah, C. T. (2017). M-Score and Z-Score for detection of accounting fraud. Accountancy Business and the Public Interest, 68-86. 
Binh, P. V. N., Trung, D. T., \& Duc, V. H. (2018). Financial distress and bankruptcy prediction: An appropriate model for listed firms in Vietnam. Economic Systems, 42(4), 616-624. https://doi.org/10.1016/j.ecosys.2018.05.002

Charalambakis, E. C., \& Garrett, I. (2019). On corporate financial distress prediction: What can we learn from private firms in a developing economy? Evidence from Greece. Review of Quantitative Finance and Accounting, 52(2), 467-491. https://doi.org/10.1007/s11156-018-0716-7

Distinguin, I., Hasan, I., \& Tarazi, A. (2010). The use of accounting data to predict bank financial distress in MENA countries. International Journal of Banking, Accounting and Finance, 2(4), 332 356. https://doi.org/10.1504/IJBAAF.2010.037154

Dobbie, W., Goldsmith-Pinkham, P., \& Yang, C. S. (2017). Consumer bankruptcy and financial health. Review of Economics and Statistics, 99(5), 853-869. https://doi.org/10.1162/REST_a_00669

El-Ansary, O., \& Bassam, L. (2019). Predicting financial distress for listed MENA firms. International Journal of Accounting and Financial Reporting, 9(2), 51. https://doi.org/10.5296/ijafr.v9i2.14542

Farooq, U., Jibran Qamar, M. A., \& Haque, A. (2018). A three-stage dynamic model of financial distress. Managerial Finance, 44(9), 1101-1116. https://doi.org/10.1108/MF-07-2017-0244

Fischer, E. O., Kampl, L.-M., \& Wöckl, I. (2019). On the valuation and analysis of risky debt: A theoretical approach using a multivariate extension of the merton model. SSRN Electronic Journal. https://doi.org/10.2139/ssrn.3450524

Franks, J. R., Sussman, O., \& Vig, V. (2016). The privatization of bankruptcy: Evidence from financial distress in the shipping industry. SSRN Electronic Journal, May. https://doi.org/10.2139/ssrn.2880751

Fredrick, I. (2019). Firm specific determinants of financial distress: Empirical evidence from Nigeria. Journal of Accounting and Taxation, 11(3), 49-56. https://doi.org/10.5897/jat2019.0333

Gao, L., He, W., \& Wang, Q. (2019). In search of distress risk in China's stock market. Global Finance Journal, 42. https://doi.org/10.1016/j.gfj.2018.08.003

Gerstrøm, A., \& Isabella, L. A. (2015). Understanding bankruptcy: How members of a bankrupted bank construe organizational death. In Illness Crisis and Loss (Vol. 23, Issue 2). https://doi.org/10.1177/1054137315575844

Gusni, Wiludjen S.P., S., \& Silviana, S. (2019). Predicting financial distress: A case study of Indonesia coal firms. Journal of Advanced Research in Dynamical and Control Systems, 11(3), 391-398.

Hantono, H. (2019). Predicting financial distress using Altman Score, Grover Score, Springate Score, Zmijewski Score (case study on consumer goods company). Accountability, 8(01), 1. https://doi.org/10.32400/ja.24056.8.01.2019.1-16

Harjito, D. A. (2016). Teori pecking order dan trade-off dalam analisis struktur modal di Bursa Efek Indonesia. Jurnal Siasat Bisnis, 15(2), 187-196. https://doi.org/10.20885/jsb.vol15.iss2.art3

Hillegeist, S. A., Keating, E. K., Cram, D. P., \& Lundstedt, K. G. (2004). Assessing the probability of bankruptcy. Review of Accounting Studies, 9(1), 5-34. https://doi.org/10.1023/B:RAST.0000013627.90884.b7

Hu, D., \& Zheng, H. (2015). Does ownership structure affect the degree of corporate financial distress in China? Journal of Accounting in Emerging Economies, 5(1), 35-50. 
Indrajati, V., Yuvita, Y., Putri, N. A., Rismawati, F. O., \& Puspitasari, D. M. (2020). Determinants of financial fistress rural Bank in Indonesia: A logit approach. Solid State Technology, 63(3), 50695075 .

Jan, A., \& Marimuthu, M. (2015). Bankruptcy and sustainability: A conceptual review on islamic banking industry. Global Business and Management Research, 7(1), 109-138.

Januri, Sari, E. N., \& Diyanti, A. (2017). The analysis of the bankruptcy potential comparative by Altman Z-Score, Springate And Zmijewski Methods at Cement Companies Listed In Indonesia Stock Exchange. IOSR Journal of Business and Management, 19(10), 80-87. https://doi.org/10.9790/487X-1910068087

Jessen, C., \& Lando, D. (2015). Robustness of distance-to-default. Journal of Banking and Finance, 50(May), 493-505. https://doi.org/10.1016/j.jbankfin.2014.05.016

Jia, Z., Shi, Y., Yan, C., \& Duygun, M. (2020). Bankruptcy prediction with financial systemic risk. European Journal of Finance, 26(7-8), 666-690. https://doi.org/10.1080/1351847X.2019.1656095

Kazemian, S., Shauri, N. A. A., Sanusi, Z. M., Kamaluddin, A., \& Shuhidan, S. M. (2017). Monitoring mechanisms and financial distress of public listed companies in Malaysia. Journal of International Studies, 10(1), 92-109. https://doi.org/10.14254/2071-8330.2017/10-1/6

Khaliq, A., Motawe Altarturi, B. H., Mohd Thas Thaker, H., Harun, M. Y., \& Nahar, N. (2014). Identifying financial distress firms: A case study of Malaysia`s government linked companies (GLC). International Journal of Economic, Finance and Management, 3(3), 141-150.

Kholisoh, S. N., \& Dwiarti, R. (2020). The analysis of fundamental variables and macro economic variables in predicting financial distress. Management Analysis Journal, 9(1), 81-90. https://doi.org/10.15294/maj.v9i1.36395

Khurshid, M. R. (2013). Determinants of financial distress evidence from KSE 100 Index. Business Review, 8(1), 7-19.

Koske, N. C., Tuwei, J. K., \& Kimwolo, A. K. (2019). Stock market liquidity and financial distress likelihood among listed firms in Nairobi securities exchange , Kenya. Journal of Economics, Finance and Accounting Studies, 1(1), 11.

Kristanti, F. T., \& Herwany, A. (2017). Corporate Governance, financial ratios, political risk and financial distress: A survival analysis. GATR Accounting and Finance Review, 2(2), 26-34. https://doi.org/10.35609/afr.2017.2.2(4)

Lawrence, J. R., Pongsatat, S., \& Lawrence, H. (2015). The use of ohlson's o-score for bankruptcy prediction in Thailand. Journal of Applied Business Research, 31(6), 2069-2078. https://doi.org/10.19030/jabr.v31i6.9468

Li, L., \& Faff, R. (2019). Predicting corporate bankruptcy: What matters? International Review of Economics and Finance, 62(February), 1-19. https://doi.org/10.1016/j.iref.2019.02.016

Li, Z., Crook, J., Andreeva, G., \& Tang, Y. (2021). Predicting the risk of financial distress using corporate governance measures. Pacific Basin Finance Journal, 68, 101334. https://doi.org/10.1016/j.pacfin.2020.101334

Lizares, R. M., \& Bautista, C. C. (2021). Corporate financial distress: The case of publicly listed firms in an emerging market economy. Journal of International Financial Management and Accounting, 32(1), 5-20. https://doi.org/10.1111/jifm.12122 
Lord, J., Landry, A., Savage, G. T., \& Weech-Maldonado, R. (2020). Predicting nursing home financial distress using the Altman Z-Score. Inquiry (United States), 57. https://doi.org/10.1177/0046958020934946

Lukason, O., \& Laitinen, E. K. (2018). Failure of exporting and non-exporting firms: do the financial predictors vary? Review of International Business and Strategy, 28(3-4), 317-330. https://doi.org/10.1108/RIBS-02-2018-0015

Matturungan, N. H., Purwanto, B., \& Irwanto, A. K. (2017). Manufacturing company bankruptcy prediction in Indonesia with Altman Z-Score Model. Jurnal Aplikasi Manajemen, 15(1), 18-24. https://doi.org/10.18202/jam23026332.15.1.03

Mavengere, K. (2015). Predicting corporate bankruptcy and earnings manipulation using the Altman Zscore and Beneish M score. The case ofZ manufacturing firm in Zimbabwe. International Journal of Management Sciences and Business Research, 10, 8-14.

Moch, R., Prihatni, R., \& Buchdadi, A. D. (2019). The effect of liquidity, profitability and solvability to the financial distress of manucatured companies listed on the Indonesia stock exchange (IDX) period of year 2015-2017. Academy of Accounting and Financial Studies Journal, 23(6), 1-16.

Mohamed, S. S. (2020). Suggested model for explaining financial distress in Egypt: Toward a comprehensive model. In R. Biswas \& M. Michaelides (Eds.), Financial Issues in Emerging Economies: Special Issue Including Selected Papers from II International Conference on Economics and Finance, 2019, Bengaluru, India (Vol. 36, pp. 99-122). Emerald Publishing Limited. https://doi.org/10.1108/S0196-382120200000036005

Monir, A. (2020). Identifying the determinants of financial distress for public listed companies in Malaysia. Jurnal Pengurusan, 59, 1-15. https://doi.org/10.17576/pengurusan-2020-59-03

Moravec, T. (2013). The bancruptcy in the czech republic - Influence of macroeconomic variables. Acta Academica Karviniensia, 13(3), 136-145. https://doi.org/10.25142/aak.2013.050

Mulyati, S. (2020). The comparative analysis of Altman Z-Score, Springate, Zmijewski, and Internal Growth Rate Model in predicting the financial distress (empirical study on mining companies listed on Indonesia Stock Exchange 2014-2017) The Comparative Analysis of Altman Z-S. Kinerja, 24(1), 82-95. https://ojs.uajy.ac.id/index.php/kinerja/article/view/3231

Nouri, B. A., \& Soltani, M. (2016). Designing a bankruptcy prediction model based on account, market and macroeconomic variables (Case Study: Cyprus Stock Exchange). Iranian Journal of Management Studies, 9(1), 125-147.

Ogachi, D., Ndege, R., Gaturu, P., \& Zoltan, Z. (2020). Corporate bankruptcy prediction model, a special focus on listed companies in Kenya. Journal of Risk and Financial Management, 13(3), 47. https://doi.org/10.3390/jrfm13030047

Olariu, D. B. (2016). Bankruptcy prediction based on the autonomy ratio. Euro Economica, 35(02), 78 92.

Osinubi, I. S. (2020). Effects of financial distress and financing constraints on trade credit provisions. Asian Review of Accounting, 28(4), 545-566. https://doi.org/10.1108/ARA-04-2020-0058

Paule-Vianez, J., Gutiérrez-Fernández, M., \& Coca-Pérez, J. L. (2020). Prediction of financial distress in the Spanish banking system: An application using artificial neural networks. Applied Economic Analysis, 28(82), 69-87. https://doi.org/10.1108/AEA-10-2019-0039 
Prasetiyani, E., \& Sofyan, M. (2020). Bankruptcy analysis using Altman Z-Score Model and Springate Model in retail trading company listed in Indonesia Stock Exchange. Ilomata International Journal of Tax and Accounting, 1(3), 139-144. https://doi.org/10.52728/ijtc.v1i3.98

Puro, N., Borkowski, N., Hearld, L., Carroll, N., Byrd, J., \& Smith, D. (2019). Financial distress and bankruptcy prediction: A comparison of three financial distress prediction models in acute care hospitals. Journal of Health Care Finance, 1-15.

Rafatnia, A. A., Ramakrishnan, S., Abdullah, D. F. B., Nodeh, F. M., \& Farajnezhad, M. (2020). Financial distress prediction across firms. Journal of Environmental Treatment Techniques, 8(2), 646-651.

Ramadhan, Y., \& Marindah, M. (2021). Financial distress analysis in an Indonesian textile company. KnE Social Sciences, 2021, 602-621. https://doi.org/10.18502/kss.v5i5.8846

Saini, V. (2018). Evaluating financial health of gujarat state fertilizers through ' $Z$ ' Score Model. $\begin{array}{llll}\text { International Journal of } & \text { Research, } & \text { 6(7), }\end{array}$ https://doi.org/10.29121/granthaalayah.v6.i7.2018.1289

Santosa, P. W., Tambunan, M. E., \& Kumullah, E. R. (2020). The role of moderating audit quality relationship between corporate characteristics and financial distress in the Indonesian mining sector. Investment Management and Financial Innovations, 17(2), 88-100. https://doi.org/10.21511/imfi.17(2).2020.08

Setyawati, I., \& Amelia, R. (2018). The role of current ratio, operating cash flow and inflation rate in predicting financial distress: Indonesia Stock Exchange. Jurnal Dinamika Manajemen, 9(2), 140 148. https://doi.org/10.15294/jdm.v9i2.14195

Susanti, N., Latifa, I., \& Sunarsi, D. (2020). The effects of profitability, leverage, and liquidity on financial distress on retail companies listed on Indonesian Stock Exchange. Jurnal Ilmiah Ilmu Administrasi Publik, 10(1), 45. https://doi.org/10.26858/jiap.v10i1.13568

Syamni, G., Majid, M. S. A., \& Siregar, W. V. (2018). Bankruptcy prediction models and stock prices of the coal mining industry in Indonesia. Etikonomi, 17(1), 57-68. https://doi.org/10.15408/etk.v17i1.6559

Tanjung, P. R. S. (2020). Comparative analysis of Altman Z-Score, Springate, Zmijewski and Ohlson models in predicting financial distress. EPRA International Journal of Multidisciplinary Research (IJMR)-Peer Reviewed Journal, 2, 126-137. https://doi.org/10.36713/epra2013

Thai, S. B., Goh, H. H., Teh, B. H., Wong, J. C., \& Ong, T. S. (2014). A revisited of Altman Z- Score Model for companies listed in Bursa Malaysia. International Journal of Business and Social Science, 5(12), 197-207.

Thinh, T. Q., Tuan, D. A., Huy, N. T., \& Thu, T. N. A. (2020). Financial distress prediction of listed companies - Empirical evidence on the Vietnamese stock market. Investment Management and Financial Innovations, 17(2), 377-388. https://doi.org/10.21511/imfi.17(2).2020.29

Tian, S., Yu, Y., \& Guo, H. (2015). Variable selection and corporate bankruptcy forecasts. Journal of Banking and Finance, 52(1), 89-100. https://doi.org/10.1016/j.jbankfin.2014.12.003

Tinoco, M. H., Holmes, P., \& Wilson, N. (2018). Polytomous response financial distress models: The role of accounting, market and macroeconomic variables. International Review of Financial Analysis, 59, 276-289. https://doi.org/10.1016/j.irfa.2018.03.017 
Tinoco, M. H., \& Wilson, N. (2013). Financial distress and bankruptcy prediction among listed companies using accounting, market and macroeconomic variables. International Review of Financial Analysis, 30, 394-419. https://doi.org/10.1016/j.irfa.2013.02.013

Toly, A. A., Permatasari, R., \& Wiranata, E. (2020). The Effect of Financial Ratio (Altman Z-Score) on Financial Distress Prediction in Manufacturing Sector in Indonesia 2016-2018. 144(Afbe 2019), 47-53. https://doi.org/10.2991/aebmr.k.200606.008

Tong, G., \& Green, C. J. (2005). Pecking order or trade-off hypothesis? Evidence on the capital structure of Chinese companies. Applied Economics, 37(19), 2179-2189. https://doi.org/10.1080/00036840500319873

Vo, D. H., Pham, B. N. V., Ho, C. M., \& McAleer, M. (2019). Corporate financial distress of industry level listings in Vietnam. Journal of Risk and Financial Management, 12(4), 155. https://doi.org/10.3390/jrfm12040155

Yazdanfar, D., \& Öhman, P. (2020). Financial distress determinants among SMEs: empirical evidence from Sweden. Journal of Economic Studies, 47(3), 547-560. https://doi.org/10.1108/JES-01-20190030

Apakah Faktor Akuntansi, Pasar, dan Makro Ekonomi Mempengaruhi Financial Distress?

Bukti di Indonesia

\begin{abstract}
Abstrak
Paper ini bertujuan untuk menginvestigasi pengaruh faktor akuntansi, pasar, dan makro ekonomi terhadap financial distress. Investigasi diperluas dengan menyusun tujuh model riset untuk mensimulasi seluruh faktor. Sampel penelitian mencakup perusahaan yang terdaftar di BEI sejak tahun 2016 hingga 2020 dimana menghasilkan 1.710 data. Paper ini menemukan bahwa retairned earning (RETA) dan earning (EBITTA) sebagai bagian dari faktor akuntansi memiliki peran memperlemah financial distress dan mampu konsisten diuji dalam beberapa model riset. Equity (MVE) sebagai bagian dari faktor market memperlemah financial distress dan konsisten diuji. Sebaliknya, meskipun solvency (SOLV) menunjukkan kemampuan perusahaan dalam memaksimalkan utang, namun tidak konsisten diuji dalam beberapa model riset. Terakhir, ditemukan keadaan deflasi yang menyebabkan terjadinya financial distress yang merepresentasi faktor makro ekonomi. Kontribusi praktis disumbangkan paper ini kepada perusahaan dan pemerintah untuk menghindari financial distress.
\end{abstract}

Kata kunci: financial distress, akuntansi, market, ekonomi 